\title{
EFFICIENCY OF SOME ALTERNATIVE INSECTICICEDS ON THE WHITE PEACH SCALE, Pseudaulacaspis pentagona (HEMIPTERA: DIASPIDIDAE).
Kwaiz,
Fayza
A. M. ${ }^{1}$;
M. M.
M. Soliman ${ }^{2}$
and \\ Sawsan G. A.Radwan ${ }^{1}$ \\ 1-Plant Protection Res. Inst., Agric. Res. Center, Dokki, Giza \\ 2-Plant Protection Dept., Faculty of Agric., South Valley University
}

\begin{abstract}
The present work was conducted to evaluate the efficiency of some alternative insecticides on the nymph and adult female populations of $P$. pentagona under laboratory and field conditions.

Two groups of alternative insecticides were evaluated, these groups were Mineral oils (Misrona oil $85 \%$ mayonnaise \& Alboleum oil $80 \%$ mayonnaise were used at rate of $2.5 \%$.) and Neem extracts (Neemix $4.5 \%$ EC \& Trilogy $90 \%$ EC were used at rate of $1 \%$ and $1.5 \%$, respectively). One Organophosphorus insecticide (Fenitrothion $50 \%$ EC at rate of $0.15 \%$ ) was used as control measure for the two alternative groups.

Laboratory bioassays of the tested alternative groups were carried out under laboratory conditions, by dipping the infested branches in the solution of each tested compound where the field evaluations were carried out in peach orchard at Qalubiya Governorate by spraying the tested alternative compounds with motor sprayer (Kobota).

The obtained results showed that, the toxicity of the alternative insecticides on the white peach scale, $P$. pentagona were varied under laboratory conditions. The highest toxicity of the tested compounds on the nymphal stage according to their LC 50 were fenitrothion $(0.183 \%)$ followed by Neemix $(0.357 \%)$. Mineral oils came in the $3^{\text {rd }}$ order [Misrona oil $(0.844 \%) \&$ Alboleum oil $(0.924 \%)$ ] whereas Trilogy came in the last order $(1.027 \%)$. The toxicity of the tested compounds on the adult female populations had the same trend, the highest toxic compounds were fenitrothion $(0.226 \%)$ followed by Neemix $(0.709 \%)$. Mineral oils came in the $3^{\text {rd }}$ order [Misrona oil $(1.368 \%)$ \& Alboleum oil (1.388\%)] and Trilogy came in the last order $(2.310 \%)$.

The efficiency of the tested alternative insecticides under field conditions after five weeks of application showed that, Mineral oils were more effective on $P$. pentagona populations, they reduced the insect populations to $89 \%$ (Misrona oil) and $88.3 \%$ (Alboleum oil), whereas Neem extracts were less effective on the insect populations $66.4 \%$ (Neemix) and $57 \%$ (Trilogy), respectively. Fenitrothion had a moderate effect on the insect populations $(79.3 \%)$.

The obtained results proved that, the Mineral oils are highly efficient as alternative insecticides for controlling the white peach scale, $P$. pentagona compared with Neem extracts. So, it prefers to use the Mineral oils for controlling the scale insects in IPM program and more studies should be carried on neen extracts to improve their efficiency for control insect pests to minimize the environmental pollution with pesticides.
\end{abstract}

\section{INTRODUCTION}

Peach, Prunus persica is economic important deciduous fruit crop in Egypt and considered as one of the popular fruits for the Egyptian peoples. 
The cultivated area with peach trees in Egypt about 83703 feddans producing about 425273 tons of fruits as estimated by Ministry of Agriculture and Land Reclamation (2007).

The white peach scale, Pseudaulacaspis pentagona (Targ.-Tozz.) is one of the most important armored scale insect infesting peach trees in Egypt. It recorded with heavily infestations on trunk, branches and twigs of peach trees, the severe infestations of $P$. pentagona affected greatly on peach trees resulting poor crop with poor quality and quantity. Wenxian, et al. (2003) showed that, the different stages of $P$. pentagona causes wilting of twigs; death of branches; defoliation and considerable yield loss.

The white peach scale, $P$. pentagona has a wide range of host plants include many agricultural crops such as fruit trees; ornamental plants and field crops (Ozawa, 1994; Ghabbour \& Mohammed, 1996; Paloukis \& Navrozidis, 1997; Kreiter \& Dijoux, 1998; Dawei, 1999 and Moharum, 2006).

Application of chemical pesticides causes serious problems such as building up of pest resistances, upsetting of natural balance and hazards to the environment. So, the present work was conducted to evaluate the efficiency of some alternative insecticides for controlling the white peach scale $P$. pentagona under laboratory and field conditions.

\section{MATERIALS AND METHODS}

Two groups of alternative insecticides were evaluated under laboratory and field conditions for controlling the white peach scale, $P$. pentagona. The evaluated groups were:

A- Mineral oils:

This group was presented with two Mineral oils compounds as follows:

1- Misrona oil 85\% Mayonnaise: Formulated by Misr Company for Petroleum

Egypt, used with rate of $2.5 \%$.

2- Alboleum oil $80 \%$ Mayonnaise: Produced by Kafr El-Zayat Company for Pesticides \& Chemical, used with rate of $2.5 \%$.

B-Neem extracts: This group presented with two Neem extracts as follows:

1- Neemix $4.5 \%$ EC: It produced by Thermo Trilogy Company /Nichimen, USA, used with of rate of $1.5 \%$.

2- Trilogy $90 \%$ EC: It produced by Thermo Trilogy Company /Nichimen, USA and used with rate of $1 \%$

C- Organophosphorus compound: This group was presented with one insecticide compound i.e. Fenitrothion 50 \% EC formulated by Sumitomo Company, used with rate of $0.15 \%$. This compound was used as control measure for the two alternatives groups.

1- Toxicity of some alternative insecticides on pre-adults and adult females of $\boldsymbol{P}$. pentagona under laboratory conditions:

Laboratory bioassays of the tested groups were carried out under laboratory conditions, using dipping method. Serial concentrations for each tested alternative insecticide were prepared by diluting the tested formulation of the insecticides. Samples of infested peach branches with pre-adults and adult females of $P$. pentagona were collected from the infested orchard and 
transferred to the laboratory. The infested branches were examined carefully and 50 branches were selected for each concentration (10 branches $/ 5$ rep.). The selected branches were dipped into each insecticide solution for 30 seconds and the control branches dipped in water only. Both treated and untreated branches left for dryness and kept in paper bags for three days. Counts of alive and dead pre-adults and adult females were carried out after three days from application. The percent of mortalities were calculated then corrected \% of mortalities was calculated according to Abbot's formula (1925). Mortality curves were drawn up on probit logarithmic graph paper, then LC50's, LC90's and slope were calculated. Toxicity index was calculated according to the method developed by Finney (1971).

$$
\text { Toxicity index }=\frac{\text { LC50 of the most active treatment } \times 100}{\text { LC50 of certain treatment }}
$$

2- Field evaluation of the tested alternative insecticides on pre-adults and adult females of $\boldsymbol{P}$. pentagona

The field evaluation was carried out in January11, 2008 at Kafr Shoker, Qalubiya Governorate at mean temperature of $13 \pm 1^{\circ} \mathrm{C}$ and $65 \%$ R.H. The peach orchard kept away from any control measures before and during the investigation. Five treatments were applied in three replications, each replicate contain three peach trees besides other three trees were left as control (untreated check).

Spraying was accomplished by motor sprayer (Kobota) with diluted solution of 13 liters/tree. Samples of 9 branches per each treatment (3 branches $X 3$ replicates) were taken as index for pre-treatment counts (preadults and adult females) whereas the post treatment counts were recorded after 1, 2, 3, 4 and 5 weeks, respectively.

The reduction percentages were estimated according to Henderson and Tilton (1955) equation. Reduction percentages of the insect populations were transferred to arc sine before conducting analysis of variance ( $F$ test) and LSD values were used to separate the means. The statistical analysis of the present work was conducted using MSTATC computer Program.

\section{RESULTS AND DISCUSSIONS}

\section{1-Toxicity of the tested alternative insecticides on the nymph and adult female stages of $\boldsymbol{P}$. pentagona under laboratory conditions.}

\section{a- Pre-adult stage:}

Data in Table (1) showed the different potencies of the five tested insecticides against the pre-adults of $P$. pentagona. Fenitrothion found to be the highly potent compound. The $\mathrm{LC}_{50}$ and $\mathrm{LC}_{90}$ values were $0.183 \%$ and $0.937 \%$. The other tested compounds were arranged according to their $\mathrm{LC}_{50}$ 's in descending order as follows: Fenitrothion; neemix; misrona; alboleum and trilogy. The $\mathrm{LC}_{50}$ 's of these tested compounds were $0.183 ; 0.357 ; 0.844$; 0.924 and $1.027 \%$ respectively and their toxicity indexes were $100 ; 51.264$; $21.682 ; 19.805$ and $17.819 \%$, respectively. The slope value is known to be a very important feature of the regression line. It is helpful in determining the 
exact reaction of population. Comparatively, low slope values indicate the heterogenic in response to the tested pesticides and have the possibility of further decrease in sensitivity after continuous uses with pesticides. The slope values in Table (1) showed that, alboleum and fenitrothion had the highest slope values i.e. 1.860 and 1.806 , respectively while trilogy had the lowest slope value (0.985).

\section{b- Adult females:}

Data in Table (1) showed the potency of the same tested alternative insecticides on the adult females of $P$. pentagona using the same technique. Considering the $\mathrm{LC}_{50}$ values for the tested insecticides, fenitrothion was the most efficient compound against adult females population followed by neemix, misrona, alboleum and trilogy. The $\mathrm{LC}_{50}$ 's of these tested compounds were $0.226 ; 0.709 ; 1.368 ; 1.388$ and $2.310 \%$ respectively and their toxicity indexes were $100 ; 31.876 ; 16.52 ; 16.282$ and $9.784 \%$ respectively.

The obtained results revealed that the tested compounds gave the same efficacy against the adult females. Results in Table (1) revealed that, the pre-adults were more susceptible to the tested compounds than the adult females of $P$. pentagona. The slope values in the same Table indicated that, neemix gave the highest slope value (3.042) followed by fenitrothion (2.781). Misrona and alboleum were almost parallel $(2.299 \& 2.103)$ whereas trilogy gave the lowest slope value (1.629).

In Japan, Ozawa (1994) investigated the effectiveness of some insecticides against $P$. pentagona on the tea crop at the laboratory and field conditions, he found that buprofezin $25 \% \mathrm{~W}$ was more effective than methidathion $40 \% \mathrm{E}$, chloropyrifos $40 \mathrm{E}$ and dichlorvos. Zhao-Shixi et al. (1997) tested seven insecticides in laboratory against $P$. pentagona they found that the insecticidal efficacy against nymphs ranged from 79.6 to $90.2 \%$ and adult females efficacy ranged from 15.4 to $41.8 \%$. Kwaiz (1999) found that profenofos insecticide had the superior effect against the pre-adult and adult females of Kilifia acuminata (Signoret) with $\mathrm{LC}_{25}, \mathrm{LC}_{50}$ and $\mathrm{LC}_{90}$ values followed by diazinon, chlorpyrifos-methyl, Malathion, KZ oil and shokrona oil.

Table (1): Toxicity of different alternative insecticides on pre-adult and adult female populations of white peach scale, $P$. pentagona under laboratory conditions.

\begin{tabular}{|c|c|c|c|c|c|c|c|}
\hline \multirow{3}{*}{ Treatment } & \multirow{2}{*}{$\begin{array}{c}\text { LC }_{50} \\
(\%)\end{array}$} & \multirow{2}{*}{$\begin{array}{c}\mathbf{L C}_{90} \\
(\%)\end{array}$} & \multirow[t]{2}{*}{ Slope \pm se } & \multicolumn{2}{|c|}{$\begin{array}{c}\text { Confidence limit at } \\
\text { LC }_{50}\end{array}$} & \multicolumn{2}{|c|}{ Toxicity index } \\
\hline & & & & Lower & Upper & $\mathbf{L C}_{50}$ & $\mathbf{L C}_{90}$ \\
\hline & \multicolumn{7}{|c|}{ Pre-adult stage } \\
\hline Fenitrothion & 0.183 & 0.937 & $1.806 \pm 0.074$ & 0.085 & 0.295 & 100 & 100 \\
\hline Neemix & 0.357 & 2.051 & $1.687 \pm 0.08$ & 0.323 & 0.390 & 51.264 & 45.69 \\
\hline Misrona & 0.844 & 5.13 & $1.636 \pm 0.069$ & 0.509 & 1.102 & 21.682 & 18.27 \\
\hline Alboleum & 0.924 & 5.022 & $1.860 \pm 0.085$ & 0.627 & 1.187 & 19.805 & 18.66 \\
\hline Trilogy & 1.027 & 18.489 & $0.985 \pm 0.058$ & 0.792 & 1.242 & 17.819 & 4.95 \\
\hline \multicolumn{8}{|c|}{ Adult stage } \\
\hline Fenitrothion & 0.226 & 0.653 & $2.781 \pm 0.089$ & 0.171 & 0.302 & 100 & 100 \\
\hline Neemix & 0.709 & 1.871 & $3.042 \pm 0.103$ & 0.543 & 0.903 & 31.876 & 34.90 \\
\hline Misrona & 1.368 & 5.051 & $2.299 \pm 0.089$ & 0.990 & 1.754 & 16.52 & 12.93 \\
\hline Alboleum & 1.388 & 5.648 & $2.103 \pm 0.074$ & 0.782 & 2.280 & 16.282 & 11.56 \\
\hline Trilogy & 2.310 & 14.143 & $1.629 \pm 0.078$ & 1.788 & 3.055 & 9.784 & 4.62 \\
\hline
\end{tabular}




\section{2- Field evaluation of the tested alternative insecticides on population of P. pentagona}

The initial effects of the tested insecticides on the pre-adult and adult female populations after one week of application as well as the residual effect after 2, 3, 4 and 5 weeks of application were shown Table (2). The obtained results showed that, the initial effect of tested insecticides after one week of application was varied on the pre-adult populations. The highest effective compound was fenitrothion (88.1\%) and the moderate effective compounds were mineral oils i.e. misrona and alboleum, they reduced the pre-adult populations to 71.6 and $72.8 \%$, respectively. The less effective compounds on the pre-adult populations were neemix and trilogy, they reduced the populations to $54.8 \%$ and $35.9 \%$, respectively. The initial effect of the tested insecticides on the adult female populations showed that, fenitrothion was the highest effective compound on the adult populations (80.2\%) followed by misrona $(75.9 \%)$ and alboleum $(71.8 \%)$ whereas the neem extracts were lower effective on the adult female populations, they reduced the populations to $62.4 \%$ (neemix) and $44.1 \%$ (trilogy), respectively.

The residual effect of the tested compounds on the nymphal populations was appeared after 2 weeks of application, the highest effective insecticides were obtained by mineral oils i.e. misrona (90.6\%) and alboleum $(88.7 \%)$ followed by fenitrothion $(80.8 \%)$. Neemix came in the $3^{\text {rd }}$ order $(71.7 \%)$ whereas trilogy gave $55.6 \%$ reduction for the pre-adult populations. The residual effect on the adult female populations were relatively higher after 2 weeks of application, the populations reduced to $86.2 \%$ (alboleum), $85.3 \%$ (misrona) and $80.5 \%$ (Fenitrothion) while neem extracts raised to $70.8 \%$ (neemix) and $67.8 \%$ (trilogy), respectively.

After 3 weeks of application, the residual effects of the tested insecticides were varied on both nymph and adult populations. The highly effective compounds on the nymphal populations were recorded by mineral oils, the percent of reduction increased to $93.6 \%$ (alboleum) and $94.1 \%$ (misrona), respectively. Fenitrothion decreased to $85.6 \%$ after 3 weeks of application compared with its initial effect (one week after application). Reduction percentages raised in neem extracts after 3 weeks of application, the populations reduced to $79.5 \%$ (neemix) and $64.8 \%$ (trilogy), respectively.

The residual effects were varied also on the adult female populations after 3 weeks of application, the highest effective compounds were mineral oils i.e., (90\%) alboleum and misrona (89.6\%) whereas the Organophosphorus insecticide (Fenitrothion) came in the $2^{\text {nd }}$ order $(79.8 \%)$. The lowest reduction percentages were recorded by neem extracts i.e. neemix $(77.5 \%)$ and trilogy $(72.3 \%)$, respectively.

The residual effects of the tested alternative insecticides on the insect populations after one month of application showed that, the mineral oils were highly effective on the pre-adult populations, they reduced the populations to 90.5\% (misrona) and $89.1 \%$ (alboleum), respectively whereas fenitrothion decreased the populations to $66.9 \%$. Neemix and trilogy were $53.2 \%$ and $59.3 \%$, respectively. 
Kwaiz, Fayza A. M. et al.

T2 
On the other hand, the residual effects of the tested compounds on the adult populations after one month of application revealed that, the mineral oils were highly effective in decreasing the populations to $90.3 \%$ (misrona) and $91.2 \%$ (alboleum) compared with fenitrothion (77.5\%); neemix $(79.5 \%)$ and trilogy $(71.5 \%)$, respectively.

The residual effects of the alternative insecticides on the insect populations after five weeks indicated the efficiency of the tested compounds against $P$. pentagona as mentioned in Table (2). The results showed that, mineral oils were more effective compounds on both pre-adult and adult female populations, they reduced the pre-adult populations to $97.8 \%$ (misrona) \& 98.2\% (alboleum) and adult populations to 91.5\% (misrona) and $89.2 \%$ (alboleum), respectively.

Fenitrothion reduced both pre-adult and adult populations to $84.7 \%$ and $71.3 \%$, respectively. Neem insecticides were less effective on the insect populations, neemix reduced the pre-adult and adult populations to $61.1 \%$ and $63.2 \%$, respectively, whereas trilogy had a poor effect on the pre-adults $(57.4 \%)$ and adult populations (36.9\%).

The average percent of reduction (\%) for the insect populations (Table, 2 ) showed that, mineral oils reduce the population of $P$. pentagona highly, they reduced the pre-adult to $90.7 \%$ (misrona) and $90.2 \%$ (alboleum) and adults to $86.8 \%$ (misrona) and $85.9 \%$ (alboleum), respectively. The Organophosphorus insecticides (Fenitrothion) had a moderate effect on the insect populations, it reduced the pre-adult populations to $80.6 \%$ and adult populations to $77.7 \%$, respectively. Neem extracts had poor effect on the insect populations, neemix reduced pre-adult populations to $64.1 \%$ and adult populations to $70.7 \%$ whereas trilogy was less effective on both pre-adults (56.3\%) and adult females (55.3\%).

The afore-mentioned results indicated that, mineral oils were more effective on $P$. pentagona populations, they reduced the insect populations to $89 \%$ (misrona oil) followed by alboleum oil (88.3\%). Fenitrothion had a moderate effect on the insect populations (79.3\%) whereas neem extracts were less effective on the insect populations, 66.4\% (neemix) and 57\% (trilogy), respectively.

Paloukis, et al., (1997) showed that using paraffin oil, mineral oils and potassium salt of fatty acids give good control for $P$. pentagona. Asfoor (1997) found that the reduction in the Parlatoria oleae populations on deciduous fruit trees by application Sumi oil reached to $81.5 \%$ followed by cidial K (80.6\%), phenthoate $(78.8 \%)$, diazinon $(77.7 \%)$, fenitrothion $(77.2 \%)$ and fenvalerate $(70.8 \%)$, respectively. Helmy et al. (2006) reported that, mineral oils were effective against Russellaspis pustulaus infesting apple trees, alboleum reduced the populations to $89.7-91.9 \%$ and folck oil 90.8 91.3\%.

El-Emery et al. (1999) demonstrated that, Malathion with rate of $0.15 \%$ and alboleum oil with rate of $2.5 \%$ reduced the populations of Parlatoria oleae (Clovee) on plum trees by $74.8 \%$ and $73.1 \%$, respectively.

The obtained results proved that, the Mineral oils are highly efficient as alternative insecticides for controlling the white peach scale, $P$. pentagona compared with Neem extracts. So, it prefers to use the Mineral oils for 
controlling the scale insects in IPM program and more studies should be carried on neen extracts to improve their efficiency for control insect pests to minimize the environmental pollution of pesticides.

\section{REFERENCES}

Abbott, W. S. (1925): A method for computing the effectiveness of an insecticide. J. Econ. Entomol. 18, pp. 265 - 267.

Asfoor, M. A. (1997): Seasonal abundance and control of the plum scale insect Parlatoria oleae (Colvee) on some deciduous trees. Ph.D. Thesis, Fac. Agric., Moshtohor, Zagazig Univ., Egypt. 398pp.

Dawei, G. (1999): Experiment of control of plum mulberry scales. South China Fruits, 28 (4):40.

El-Imery, S. M.; G. H. Sewify; M. F. Tawfik and N. A. Ezz (1999): Bio-residual effect of some scalicides on the plum scale insect, Parlatoria olea (Colvee) and its parasitoid, Aphytis sp. $2^{\text {nd }}$ Int. Conf. of pest control, Mansoura, Egypt.pp:199- 204.

Finney, D. J. (1971): Probit analysis, Cambridge University Press. $3^{\text {rd }}$ Edn, pp. 333.

Ghabbour, M. W. and Z. K. Mohammed (1996): The Diaspididae of Egypt (Coccoidea: Diaspididae). J. Egypt Ger. Soc. Zool., 21 (E) Entomol. 337-369.

Hendrson, C. F. and E. W. Tilton (1955): Test with acaricides against the brown wheat mite. J. Econ. Entomol. 48:157-161.

Kreiter, P. and L. Dijoux (1998): White peach scale in a peach orchard. A control example in the Maritime Alps. Phytoma. 50(501):36-40.

Kwaiz, F. (1999): Ecological and toxicological studies on the mango soft scale Kilifia acuminata (Signoret) with special reference to insecticide residues in mango fruits. Ph.D Thesis Fac. Of Agric., Cairo Univ., Egypt. $171 \mathrm{pp}$.

Helmy, E. I. ; Kwaiz, F. A. and S. G. Radwan (2006):Mineral oils as safe altenative pesticides against Russellaspis (= Asterolrcanium pustulans) pustulans (Cockerell) (Homoptera; Coccoidea: Asterolecaniidae) on apple at El-Nobariya district, Egypt. Egypt. J. Appl. Sci., 21(10B):786793.

Moharum, F. (2006): Ecological and morphological studies on the white peach scale, Pseudaulacaspis pentagona and its natural enemies. Ph.D. Thesis, Fac. Agric. Moshtohor, Zagazig Univ., Egypt. 180PP.

Ozawa, A. (1994): The occurrence of white peach scale, Pseudaulacaspis pentagona (Targ.-Tozz.), in tea fields and its chemical control. III. Effect of various pesticides in the control of the scale. Proceedings of the kanto Tosan Plant Protection Society (41): $257-259$.

Paloukis, S. S. and E. I. Navrozidis (1997): Integrated control of Pseudaulacaspis pentagona (Targ.-Tozz.) (Homoptera, Diaspididae) on peach and kiwi trees in Northern Greece. Bolletino. Laboratorio. Entomologia Agraria `Filippo Silvestri`. 52:111-116. 
Paloukis, S. S.; Navrozidis, E. I. and V. H. Kukuryanis (1997): Contribution to the integrated control of Pseudaulacaspis pentagona Targ. (Homoptera: Diaspidiae) on Kiwi fruit trees (Actinidia chinensis). Acta Horticulturae (444): $797-802$

Wenxian, P.; Yincai, E; Wei, Z. and J. Xiaofan (2003): Occurrence and control of Pseudaulacaspis pentagona in the Northern Zhejiang. J. Zhejiang Forestry Science and Technology. 23(1): 44-46.

Zhao-Shixi; Fan-Qinghai and Guo-Dawei (1997): Chemical control of white peach scale, Pseudaulacaspis pentagona living on nane tree. Wuyi Science Journal (13): $193-197$.

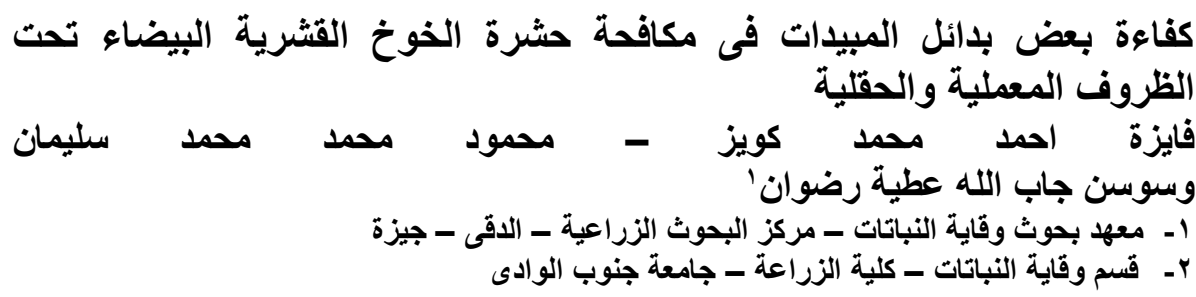

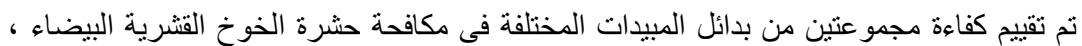

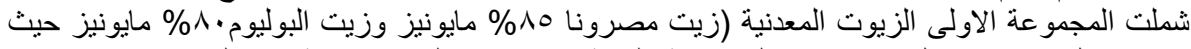

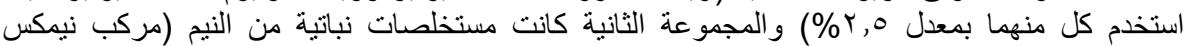

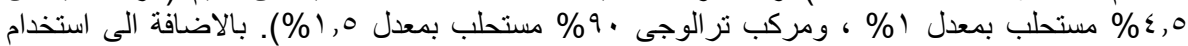

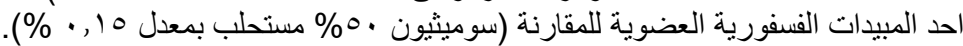

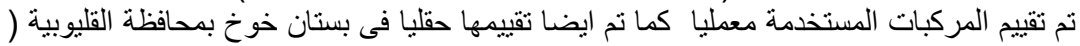

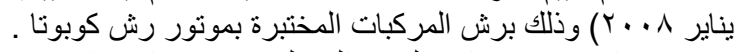

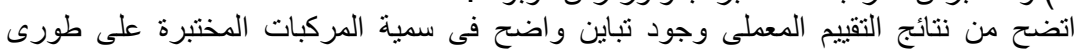

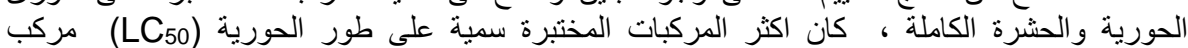

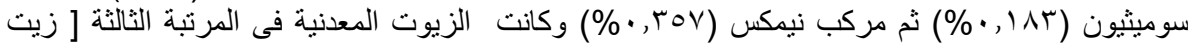

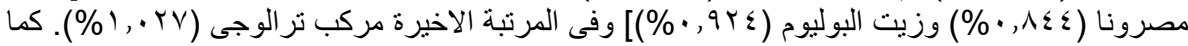

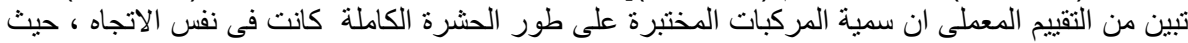

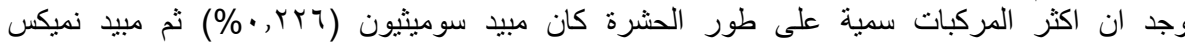

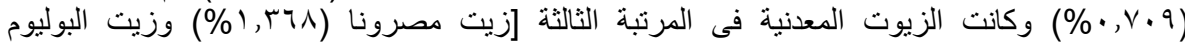

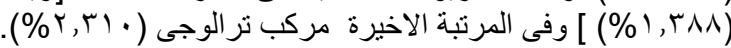

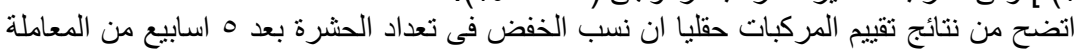

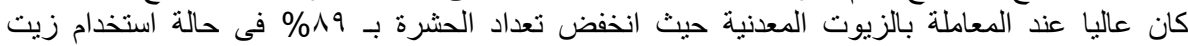

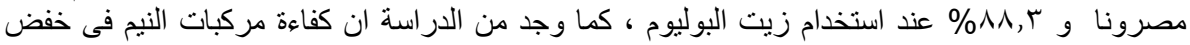

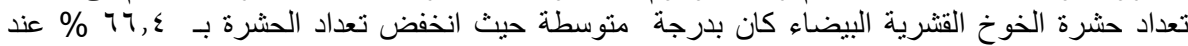

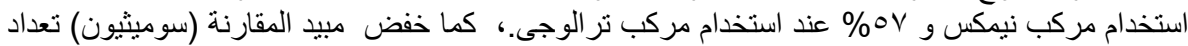

وقد تبين من الدراسة كفاعة الزيوت المعدنية كأحد بدائل المبيدات فى مكافحة حشرة الخوخ القشرية الحشرة بـ \% \%

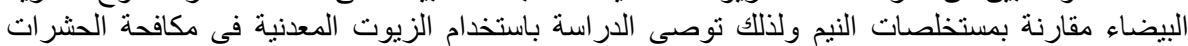

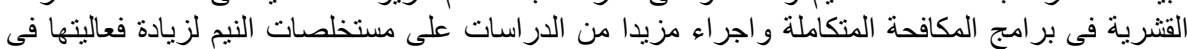
مكافحة الافات الحشرية والحد من استخدام المبيدات الكيماوية للمحافظة على البيئة. 
Kwaiz, Fayza A. M. et al. 
Table (2): Efficiency of some alternative insecticides on the white peach scale, $P$. pentagona infesting peach trees in Qalubiya Governorate.

\begin{tabular}{|c|c|c|c|c|c|c|c|c|c|c|c|c|c|c|c|c|c|c|c|c|c|c|}
\hline \multirow{5}{*}{$\begin{array}{l}\text { Evaluated } \\
\text { insecticide }\end{array}$} & \multirow{5}{*}{$\begin{array}{l}\text { Rate/ } \\
\text { Liter }\end{array}$} & \multirow{3}{*}{\multicolumn{3}{|c|}{ Pre-spraying count }} & \multicolumn{15}{|c|}{ Post spraying counts } & \multirow{3}{*}{\multicolumn{3}{|c|}{$\begin{array}{l}\text { Average percent } \\
\text { of reduction }\end{array}$}} \\
\hline & & & & & \multirow{2}{*}{\multicolumn{3}{|c|}{$\begin{array}{c}\text { Initial effect } \\
\text { One week } \\
\end{array}$}} & \multicolumn{12}{|c|}{ Residual effect } & & & \\
\hline & & & & & & & & \multicolumn{3}{|c|}{ Two weeks } & \multicolumn{3}{|c|}{ Three weeks } & \multicolumn{3}{|c|}{ Four weeks } & \multirow{2}{*}{\multicolumn{3}{|c|}{$\begin{array}{c}\text { Five weeks } \\
15 / 1 / 2008\end{array}$}} & & & \\
\hline & & & 11/1/200 & & & $3 / 1 / 20$ & & & $\begin{array}{l}5 / \mathbf{1} / 200 \\
\end{array}$ & & & /2/2008 & & & $8 / 2 / 2008$ & & & & & \multicolumn{3}{|c|}{ Total population } \\
\hline & & \begin{tabular}{|c|}
$\begin{array}{c}\text { Pre- } \\
\text { adult }\end{array}$ \\
\end{tabular} & \begin{tabular}{|c|} 
Adult \\
female
\end{tabular} & Total & \begin{tabular}{|c|} 
Pre- \\
adult
\end{tabular} & \begin{tabular}{|r|} 
Adult \\
female
\end{tabular} & Total & \begin{tabular}{|c|} 
Pre- \\
adult
\end{tabular} & \begin{tabular}{|c|}
$\begin{array}{r}\text { Adult } \\
\text { female }\end{array}$ \\
\end{tabular} & Total & \begin{tabular}{|c|}
$\begin{array}{c}\text { Pre- } \\
\text { adult }\end{array}$ \\
\end{tabular} & \begin{tabular}{|l|} 
Adult \\
female
\end{tabular} & Total & \begin{tabular}{|c|} 
Pre- \\
adult
\end{tabular} & \begin{tabular}{|l|} 
Adult \\
fit \\
\end{tabular} & Total & $\left|\begin{array}{|c|}\text { Pre- } \\
\text { adult }\end{array}\right|$ & \begin{tabular}{|c|} 
Adult \\
female
\end{tabular} & Total & $\left|\begin{array}{c|}\text { Pre- } \\
\text { adult }\end{array}\right|$ & \begin{tabular}{|c|} 
Adult \\
female
\end{tabular} & Total \\
\hline \multirow{2}{*}{\begin{tabular}{|l|} 
Misrona Oil \\
$85 \%$ \\
(Mayonnaise)
\end{tabular}} & \multirow[b]{2}{*}{$2.5 \%$} & 98 & 104 & 202 & 33.0 & 28.4 & 61.4 & 14.0 & \begin{tabular}{|l|}
18.0 \\
\end{tabular} & 32.0 & 11.0 & 13.0 & 24.0 & 19.0 & 12.8 & 31.8 & 5.0 & 11.8 & 16.8 & 16.4 & 16.8 & 33.2 \\
\hline & & & & & $\begin{array}{c}71.6 \\
\%\end{array}$ & $\begin{array}{c}75.9 \\
\%\end{array}$ & $73.8 \%$ & $\begin{array}{c}90.6 \\
\%\end{array}$ & $\begin{array}{c}85.3 \\
\% \\
\end{array}$ & $\begin{array}{c}88.2 \\
\%\end{array}$ & \begin{tabular}{|c|}
94.1 \\
$\%$
\end{tabular} & $\begin{array}{c}89.6 \\
\%\end{array}$ & $\begin{array}{c}92.2 \\
\%\end{array}$ & $\begin{array}{c}90.5 \\
\%\end{array}$ & $90.3 \%$ & $\begin{array}{c}90.4 \\
\% \\
\end{array}$ & $97.8 \%$ & $\begin{array}{c}91.5 \\
\%\end{array}$ & $\begin{array}{c}95.3 \\
\%\end{array}$ & $\begin{array}{c}90.7 \mathbf{a} \\
\%\end{array}$ & $\begin{array}{c}86.8 \mathbf{a} \\
\%\end{array}$ & $\begin{array}{c}89.0 \mathrm{a} \\
\%\end{array}$ \\
\hline \multirow{2}{*}{\begin{tabular}{|l|} 
Alboleum Oil \\
$80 \%$ \\
(Mayonnaise)
\end{tabular}} & \multirow[b]{2}{*}{$2.5 \%$} & \multirow[t]{2}{*}{99} & \multirow[t]{2}{*}{98} & \multirow[t]{2}{*}{197} & 32.0 & 31.4 & 63.4 & 17.0 & 16.0 & 33.0 & 12.0 & 11.8 & 23.8 & 22.0 & 11.0 & 33.0 & 4.0 & 14.2 & \begin{tabular}{|l|}
18.2 \\
\end{tabular} & 17.4 & 16.9 & 34.3 \\
\hline & & & & & $\begin{array}{c}72.8 \\
\%\end{array}$ & $\begin{array}{c}71.8 \\
\%\end{array}$ & $72.2 \%$ & $\begin{array}{c}88.7 \\
\%\end{array}$ & $\begin{array}{c}86.2 \\
\%\end{array}$ & $\begin{array}{c}87.5 \\
\%\end{array}$ & $\begin{array}{c}93.6 \\
\%\end{array}$ & $\begin{array}{c}90.0 \\
\%\end{array}$ & $\begin{array}{c}92.1 \\
\% \\
\end{array}$ & $\begin{array}{c}89.1 \\
\%\end{array}$ & $91.2 \%$ & $\begin{array}{c}89.7 \\
\%\end{array}$ & $98.2 \%$ & $\begin{array}{c}89.2 \\
\% \\
\end{array}$ & $\begin{array}{c}94.8 \\
\%\end{array}$ & $\begin{array}{c}90.2 \mathrm{a} \\
\%\end{array}$ & $\begin{array}{c}85.9 \mathrm{a} \\
\%\end{array}$ & $\begin{array}{c}88.3 a \\
\%\end{array}$ \\
\hline \multirow{2}{*}{$\begin{array}{l}\text { Fenitrothion } \\
50 \% \text { EC. }\end{array}$} & \multirow[b]{2}{*}{$0.15 \%$} & \multirow[t]{2}{*}{99} & \multirow[t]{2}{*}{107} & \multirow[t]{2}{*}{206} & 14.0 & 24.0 & 38.0 & 29.0 & 24.6 & 53.6 & 27.0 & 26.0 & 53.0 & 67.0 & 30.6 & 97.6 & 34.8 & 41.0 & \begin{tabular}{|c|}
75.8 \\
\end{tabular} & 34.4 & 29.2 & 63.6 \\
\hline & & & & & $\begin{array}{c}88.1 \\
\%\end{array}$ & $\begin{array}{c}80.2 \\
\%\end{array}$ & $84.1 \%$ & $\begin{array}{c}80.8 \\
\%\end{array}$ & $\begin{array}{c}80.5 \\
\%\end{array}$ & $\begin{array}{c}80.6 \\
\%\end{array}$ & $\begin{array}{c}85.6 \\
\%\end{array}$ & $\begin{array}{c}79.8 \\
\% \\
\end{array}$ & $\begin{array}{c}83.2 \\
\%\end{array}$ & $\begin{array}{c}66.9 \\
\%\end{array}$ & $.5 \%$ & $\begin{array}{c}71.0 \\
\%\end{array}$ & 6 & $\begin{array}{c}71.3 \\
\%\end{array}$ & $\begin{array}{c}79.4 \\
\%\end{array}$ & $\begin{array}{c}80.6 \mathrm{~b} \\
\%\end{array}$ & $\begin{array}{c}77.7 \mathrm{~b} \\
\%\end{array}$ & $\begin{array}{c}79.3 \mathrm{~b} \\
\%\end{array}$ \\
\hline \multirow{2}{*}{$\begin{array}{l}\text { Neemix } \\
4.5 \% \text { E.C. }\end{array}$} & \multirow[b]{2}{*}{$1 \%$} & \multirow[t]{2}{*}{95} & \multirow[t]{2}{*}{96} & \multirow[t]{2}{*}{191.0} & 51.0 & 41.0 & 92.0 & 41.0 & 33.0 & 74.0 & 37.0 & 26.0 & 63.0 & 91.0 & 25.0 & 116.0 & 85.0 & 47.2 & 132.2 & 61.0 & 34.4 & 95.4 \\
\hline & & & & & $\begin{array}{c}54.8 \\
\%\end{array}$ & $\begin{array}{c}62.4 \\
\% \\
\end{array}$ & $58.4 \%$ & $\begin{array}{c}71.7 \\
\%\end{array}$ & $\begin{array}{c}70.8 \\
\% \\
\end{array}$ & $\begin{array}{c}71.1 \\
\%\end{array}$ & $\begin{array}{c}79.5 \\
\%\end{array}$ & $\begin{array}{c}77.5 \\
\%\end{array}$ & $\begin{array}{c}78.4 \\
\%\end{array}$ & $\begin{array}{c}53.2 \\
\%\end{array}$ & $79.5 \%$ & $\begin{array}{c}62.8 \\
\%\end{array}$ & $61.1 \%$ & $\begin{array}{c}63.2 \\
\%\end{array}$ & $\begin{array}{c}61.3 \\
\%\end{array}$ & $\begin{array}{c}64.1 \mathrm{c} \\
\%\end{array}$ & $\begin{array}{c}70.7 \mathrm{c} \\
\%\end{array}$ & $\begin{array}{c}66.4 \mathrm{c} \\
\%\end{array}$ \\
\hline & & 96 & 105 & 201 & 73.0 & 66.6 & 139.6 & 65.0 & 39.8 & 104.8 & 64.0 & 35.0 & 99.0 & 80.0 & 38.0 & 118.0 & 94.0 & 88.5 & 182.6 & 75.2 & 53.6 & 128.6 \\
\hline $90 \%$ EC. & $1.5 \%$ & & & & $\begin{array}{c}35.9 \\
\%\end{array}$ & $\begin{array}{c}44.1 \\
\%\end{array}$ & $40.7 \%$ & $\begin{array}{c}55.6 \\
\%\end{array}$ & $\begin{array}{c}67.8 \\
\%\end{array}$ & $\begin{array}{c}61.1 \\
\%\end{array}$ & $\begin{array}{c}64.8 \\
\%\end{array}$ & $\begin{array}{c}72.3 \\
\%\end{array}$ & $\begin{array}{c}67.8 \\
\%\end{array}$ & $\begin{array}{c}59.3 \\
\%\end{array}$ & $71.5 \%$ & {$\left[\begin{array}{c}64.0 \\
\%\end{array}\right.$} & $57.4 \%$ & $\begin{array}{c}36.9 \\
\%\end{array}$ & $\begin{array}{c}49.1 \\
\%\end{array}$ & $\begin{array}{c}56.3 \mathrm{~d} \\
\%\end{array}$ & $\begin{array}{c}58.3 \mathrm{~d} \\
\%\end{array}$ & $\begin{array}{c}57 d \\
\%\end{array}$ \\
\hline Contro & & 107 & 122.2 & 229.2 & 127.0 & 138.6 & 265.6 & 163.0 & 144.03 & 307.0 & 202.8 & 147.2 & 350.0 & 219.0 & \begin{tabular}{l|l|l} 
& 155.23
\end{tabular} & 374.2 & 246.0 & $|163.4|$ & 409.4 & 191.6 & 149.7 & 7341.2 \\
\hline value: & & & & & & & & & & & & & & & & & & & & 2534 & 32.75 & 20.81 \\
\hline & & & & & & & & & & & & & & & & & & & & |0.57 & 3.41 & 1.56 \\
\hline
\end{tabular}

Means in the same column not followed by the same letter is significantly different $(P<0.05)$ using LSD test in MSTATC computer Program. 